\title{
The appearance of human nature in the artwork of Kazuo Ishiguros
}

\author{
Madina IRSALIYEVA ${ }^{1}$ \\ National University of Uzbekistan after named Mirzo Ulug'bek
}

\begin{tabular}{l} 
ARTICLE INFO \\
\hline Article history: \\
Received February 2021 \\
Received in revised form \\
20 February 2021 \\
Accepted 15 March 2021 \\
Available online \\
15 April 2021 \\
\hline
\end{tabular}

\footnotetext{
Keywords:

Kazuo Ishiguro, never let me go,

human,

humanity,

human nature,

characters of the novel,

imagination.
}

\section{ABSTRACT}

This article proposes a diachronic approach to Ishiguro's novels aiming at inscribing his last novel in a reflection on the nature of humanity. Thus, Kazuo proved to have a delicate spirit by being able to place unprecedented storms, hurricanes, and great storms in a very convincing way. "Never Let Me Go" 31-year-old Kathy Sh. is based on the touching events of the girl's years of private schooling and her subsequent life. The author skillfully depicts the love and donation of the protagonists Tommy and Ruth, so that it seems natural for Kathy to become a donor and donate her body parts to patients.

2181-1415/C 2021 in Science LLC.

This is an open access article under the Attribution 4.0 International (CC BY 4.0) license (https://creativecommons.org/licenses/by/4.0/deed.ru)

\section{Kadzuo Ishiguro badiiy asarida inson tabiatining ko'rinishi}

\section{Kalit so'zlar:}

Kadzuo Ishiguro,

hech qachon meni qo'yib

yubormang,

inson,

insonparvarlik,

inson tabiati,

roman qahramonlari,

tasavvur.

\section{ANNOTATSIYA}

Ushbu maqola Ishiguroning romanlariga, uning so'nggi romanini insoniyat tabiatida aks ettirishga qaratilgan diaxronik yondashuvni taklif qiladi. Shunday qilib Kadzuo nozik ruhiyat egasi ekanini mislsiz po'rtanalar, dovullarni, haybatli to'fonlarni sokinlik, vazminlik bag'riga g'oyat ishonarli tarzda joylashtira olishi bilan isbotladi. "Meni qo'yib yuborma" asarida 31 yashar Keti Sh. ismli qizning xususiy maktabda ta'lim olgan yillarida sodir bo'lgan ta'sirchan voqealar va undan keyingi hayoti asosiga qurilgan. Adib shu qadar mahorat bilan asar qahramonlari Tommi va Rutning muhabbati hamda donorlik taqdirini chizib beradiki, natijada Keti ham donorga aylanib, o'z tana a'zolarini kasallarga berishi tabiiy ko'rinadi.

\footnotetext{
${ }^{1}$ Lecturer of National University of Uzbekistan after named Mirzo Ulug'bek, Tashkent, Uzbekistan
} 


\section{Облик человеческой природы в художественном произведении Кадзуо Ишигуро}

\author{
Ключевые слова: \\ Кадзуо Ишигуро, \\ никогда не отпускай меня, \\ человек, \\ человеколюбие, \\ человеческая природа, \\ персонажи романа, \\ воображение.
}

\begin{abstract}
АННОТАЦИЯ
В этой статье предлагается диахронический подход к романам Ишигуро с целью вписать его последний роман в размышления о природе человечества. Таким образом, Кадзуо оказался тонким духом, способным очень убедительно устраивать беспрецедентные штормы, ураганы и сильные штормы. Произведение «Не отпускай меня» основана на трогательных событиях, связанных с частным обучением 31-летней Кэти Ш. и ее последующей жизни. Автор умело изображает любовь и пожертвование главных героев Томми и Рут, что для Кэти кажется естественным стать донором и жертвовать часть своего тела пациентам.
\end{abstract}

I am a writer who wishes to write international novels. What is an "international" novel? I believe it to be one, quite simply, that contains a vision of life that is of importance to people of varied backgrounds around the world. It may concern characters who jet across continents, but may just as easily be set firmly in one small locality.

Kazuo Ishiguro

\section{Introduction}

The author of the words above Kazuo Ishiguro was born in Nagasaki in 1954 and moved with his family to the small town of Guildford, in southern England. He didn't return to Japan for twenty-nine years. He is known as a British novelist, screenwriter, musician, and short-story writer. The genre of his works are fiction, science fiction and fantasy. To date, Ishiguro has published eight books as well as many short stories, television and film scripts. His career may seem disjointed when focusing on only the best-known novels, "The Remains of the Day" and "Never Let Me Go". And also the writer won the Nobel Prize for his novel. According to J. Ardam a teacher in Colby College, Ishiguro won the Nobel Prize because he writes about the human condition. The British well-known writer is 67 years old now, so he is being interviewed by several researches.

\section{Literature review}

The question of what it means to be human pervades Kazuo Ishiguro's novel Never Let Me Go, which gradually reveals a counterfactual twentieth-century England where clone colonies provide ready supplies of organs for donation. Romantic-inspired views of empathy rely on the claim that art reveals the human soul, Ishiguro's novel implies that the concept of the soul invokes a fundamentally exploitative discourse of use value. In this respect, Never Let Me Go shares in a pervasive late-twentieth-century cultural skepticism about the viability of empathetic art. (Shameem Black)

Hannah Isaac elaborates on the following statement: "The characters in the novel believe (or hope, or cling to the idea that) if clones are truly human, they have souls. These souls can potentially be revealed through their artwork, but are most evident to the reader 
in the clones' ability to feel and to love. Moreover, these are traits connected with human nature and human identity in the world of the story, as the rumor about deferrals spreads so thoroughly among the former students who cling to a chance at prolonged love and life".

According to Martin Šemelák who is a PhD candidate at Palacký University in Olomouc: In Kazuo Ishiguro's novel Never Let Me Go, where the protagonist Kathy H. gradually reveals the terrifying truth about the donation program and portrays herself and her friends as victims of the atrocious establishment of the alternative England, the author has opened numerous debates related to its theme: be it the moral and ethical aspects of cloning, subject identity, bio politics or the problems of transhumanism.

\section{Research methodology}

"You had success with your fiction right from the start - but was there any writing from your youth that never got published?" This thoughtful question was given byFrench researcher Susannah Hunnewell in his interview in 2008. Kazuo Ishiguro answered: "After university, when I was working with homeless people in west London, I wrote a half-hour radio play and sent it to the BBC. It was rejected but I got an encouraging response. It was kind of in bad taste, but it's the first piece of juvenilia I wouldn't mind other people seeing. It was called "Potatoes and Lovers". When I submitted the manuscript, I spelled potatoes incorrectly, so it said potatoes. It was about two young people who work in a fish-andchips café. They are both severely cross-eyed, and they fall in love with each other, but they never acknowledge the fact that they're cross-eyed. It's the unspoken thing between them. At the end of the story they decide not to marry, after the narrator has a strange dream where he sees a family coming toward him on the seaside pier. The parents are cross-eyed, the children are cross-eyed, the dog is cross-eyed, and he says, All right, we're not going to marry". Even in this unpublished story it is seen the view of human nature.

It can be said Ishiguro makes us who we are - that which is inside us, or that which we make? Our perception of ourselves, or how others perceive us? In his novel "Never Let Me Go", Kazuo Ishiguro shows us a bleak alternate future in which humans mercilessly breed clones to provide organs, thereby eliminating concerns over cancer and other such illnesses. It is a novel about a group of young people who are also clones. These clones will grow up and begin to donate their organs in their late teens and twenties and then they will die slow, orchestrated deaths; their bodies will be used to save the lives of others. The clones have been created by a vast government program and there is no escape from it. The science is never fully explained, but it is clear that the clones are really no different from the humans they come from, except for their origin and ultimate purpose determined, of course, by humans. Ishiguro demonstrates the humanity of the clones through the narrator, Kathy, her friends Tommy and Ruth, and the story of how they grew up at Hailsham School, essentially a humane care center in which the clone children can learn and develop. So the novel is narrated by Kath, who is a carer, which means quite literally that she cares emotionally for other clones going through the donation process. In the first paragraph of the novel, Kath tells us that she's about to wrap up her work as a carer, that she soon will become a donor. When the novel begins, we don't quite know what this means. We find out everything very slowly. In the well-known novel "Never Let Me Go", Ishiguro explores human nature through the eyes of characters who are not human, but who make us question our humanity all the same. 


\section{Analysis and results}

In novel "Never Let Me Go" the students at Hailsham are taught that creativity is the most important trait they can develop - art, and the artistic products they produce, drive the social world of Hailsham School. Kathy tells the reader about the Sales and the Exchanges, explaining how art fuels the student economy, and it becomes clear that social standing is determined by artistic skill and being selected for Madame's "Gallery." Madame is a mysterious woman who visits Hailsham several times a year to collect the best art from the children, and her Gallery later becomes the center of a conspiracy, a false rumor started that it was used to determine which clones could be given more time to donate in order to spend extra years with loved ones. In this way, art is equated with the soul, and therefore with humanity itself. The children believe that the purpose of the Gallery is to show who they are - they do not realize that it's meant to show that they are at all.

When the adult Kathy and Tommy, now in love, find Madame and their former headmistress Miss Emily in hopes of getting a donation deferral, Kathy mentions a moment she had previously described to the reader, in which Madame caught her dancing to "Never Let Me Go," a sad ballad, pretending to clutch a baby to her chest: "You were... upset that day. You were watching me, and when I realised, and I opened my eyes, you were watching me and I think you were crying... Why was that?" (P. 270-271). Madame explains how she interpreted the incident: "When I came in... I saw you, by yourself, a little girl, dancing... I saw a new world coming rapidly... a harsh, cruel world. And I saw a little girl, her eyes tightly closed, holding to her breast the old kind world, one that she knew in her heart could not remain, and she was holding it and pleading, never to let her go" (P. 271-272). In this moment, where Madame saw Kathy dance, and lovingly clutch something to her heart, she finally saw the clone as something more than merely a creature - Kathy became more human, a "little girl." Kathy uses her body, what Madame thought was her only thing of value, to create art and show emotion. Madame sees the awful truth in the words "never let me go," the truth that Kathy, and all the other clones she is in school with, will be forced to let everything go; their relationships, their freedom, and their organs, therefore their bodies and very lives, lives which have meaning and complexity just as human lives do. "We took away your art because we thought it would reveal your souls. Or to put it more finely, we did it to prove you had souls at all" (p. 261). Kathy and Tommy are shocked to discover that anyone could think they didn't have souls, especially given the love they feel and the art they have produced for years. With this revelation, the hope starts to fade away and misunderstanding takes its place.

\section{Conclusion}

Throughout the novel, we see clones interacting just as humans do - they form friendships and rivalries, develop romantic feelings and jealousies, and they go in search of their human counterparts. They create beautiful art and seek to better themselves through knowledge and experience. There is nothing to separate them from humans, and yet Miss Emily confesses that all humans, including herself, are afraid of the clones, that every day she had to fight off her revulsion of them. So while we may want to think that what makes the human is something good, like art and emotion, the message of the novel is even more bleak than the world it presents - that what makes the human is the willingness to keep others down to continue the status quo. 


\section{References}

1. Black, Shameem. "Ishiguro's Inhuman Aesthetics”. Modern Fiction Studies (2009.)

2. Camus A. 1991. The Myth of Sisyphus and Other Essays. Translated by Justin O’Brien. New York: Vintage Books. PDF file.

3. Heidegger M. 1962. Being and Time. Translated by John Macquarrie and Edward Robinson.

4. Oxford: Blackwell Publishing Ltd. PDF version. ISBN: 0-631-19770-2 Ishiguro K. 2006. Never Let Me Go. London: Vintage.

5. Levy T. 2011. "Human Rights Storytelling and Trauma Narrative in Kazuo Ishiguro's Never Let Me Go" In Journal of Human Rights, 10: 1, 1-16.

6. Sartre J.P. 1946. Existentialism is Humanism. From a public lecture given in 1946.

7. https://www.researchgate.net/publication/331127466_The_suffering_of_existe nce_in_Kazuo_Ishiguro's_Never_Let_Me_Go.

8. https://files.eric.ed.gov/fulltext/EJ1153509.pdf.

9. Marc Felsbrecher (Author), 2014, Empathy in Kazuo Ishiguro's "Never Let Me Go", Munich, GRIN Verlag, https://www.grin.com/document/307097.

10. https://www.jstor.org/stable/10.5325/intelitestud.21.2.0109?seq=1'. 